\title{
MORPHOMETRIC STUDY AND DENSITY OF Telescopium telescopium IN MANGROVE ECOSYSTEM OF SEKODI VILLAGE, BENGKALIS REGENCY, RIAU PROVINCE
}

\author{
M Abdi Alka ${ }^{*}$, Aras Mulyadi ${ }^{2}$, Syafruddin Nasution $^{2}$ \\ ${ }^{1}$ Student of The Faculty of Fisheries and Marine Universitas Riau, Pekanbaru \\ ${ }^{2}$ Lecturer at The Faculty of Fisheries and Marine Universitas Riau, Pekanbaru \\ *abdialka01@gmail.com
}

\begin{abstract}
This research was conducted in August 2019 to determine the morphometric, density and sex ratio of Telescopium telescopium in Sekodi Village, Bengkalis Regency, Riau Province. Three sampling stations with three transects in each station were surveyed. The results showed that size of $T$. telescopium in areas far from community settlement were bigger than areas in the fishing boat lane and community settlement : $7.2 \mathrm{~cm}, 5.8 \mathrm{~cm}$ and 5.7 $\mathrm{cm}$. The highest density was in areas community settlement and the lowest in the fishing boat lane. ANOVA test showed that there are no different of density between all the station. Sex ratio showed that $T$. telescopium was in the balance category (1:1)
\end{abstract}

Keywords: Sekodi Village, T. telescopium, Morphometric, Density, Mangrove

\section{PENDAHULUAN}

Kabupaten Bengkalis memiliki luasan hutan mangrove sebesar 33.016 Hektar (Badan Pusat Statistik Kabupaten Bengkalis, 2015). Hutan mangrove merupakan komunitas vegetasi pantai tropis, yang didominasi oleh beberapa spesies pohon mangrove yang mampu tumbuh dan berkembang pada daerah pasang-surut pantai berlumpur. Telescopium telescopium merupakan salah satu jenis Gastropoda yang banyak hidup di air payau atau hutan manggrove yang di dominasi oleh pohon bakau (Rhizopora sp) sehingga orang menyebutnya sebagai keong bakau.

Gastropoda adalah hewan hermafrodit, tetapi tidak mampu auto fertilsasi. Ova dan spermatozoa dibentuk bersama-sama di ovotestis. Ovotestis berupa kelenjar kecil berwarna putih kemerahan, terletak melekat diantara kelenjar pencernaan. Saluran yang terdapat pada ovotestis yaitu duktus hermaproditikus, spermoviduk yang terdiri dari dua saluran yaitu saluran telur dan semen.

Pengukuran morfometrik pada gastropoda diperlukan untuk mengetahui panjang dan lebar serta skala kondisi fisik sesuai fase hidup hewan. Mengukur bagian tubuh hewan bertujuan untuk mengetahui kisaran ukurannya sehingga didapatkan informasi mengenai jenis spesies gastropoda yang diamati.

Nisbah kelamin sebagai salah satu parameter reproduksi diukur untuk menentukan kemungkinan tersedianya induk jantan dan induk betina yang diharapkan dapat terjadi pemijahan. Dalam kondisi normal, rasio jenis kelamin jantan dan betina ditunjukkan dengan rasio jenis kalamin jantan dan betina antara satu (1) jantan berbanding satu (1) betina. Selain itu, nisbah kelamin dapat pula menunjukkan adanya eksploitasi yang berlebihan terhadap salah satu jenis 
kelamin maupun indikasi adanya perubahan lingkungan (Effendi, 2002).

Kabupaten Bengkalis khususnya Desa Sekodi juga berhadapan langsung dengan Selat Melaka yang merupakan jalur perlayaran internasional tersibuk nomor dua di dunia. Padatnya aktivitas di pesisir Kabupaten Bengkalis tersebut memiliki dampak seperti terjadinya tumpahan minyak diprediksikan menyebabkan hutan mangrove dan biota asosiasinya menjadi rawan terhadap pencemaran dan berdampak terhadap kepadatan biota di daerah Desa Sekodi, termasuk gastropoda.

Penelitian yang mengkaji morfometrik gastropoda belum banyak yang melakukan. Salah satu upaya untuk membandingkan karakteristik morfologi siput, maka diperlukan studi morfometrik.

Tujuan Penelitian ini adalah untuk mengetahui konsentrasi nitrat, fosfat dan silikat, menganalisis kelimpahan diatom planktonik di sekitar perairan Meral serta menganalisis hubungan konsentrasi nitrat, fosfat dan silikat hubungannya dengan kelimpahan diatom planktonik di perairan Meral.

\section{METODE PENELITIAN}

Metode yang digunakan dalam penelitian ini adalah metode survei. Sampel yang diperoleh dari Desa Sekodi (Gambar 1) dianalisis di Laboratorium Biologi Laut dan Kimia Laut Jurusan Ilmu Kelautan Fakultas Perikanan dan Kelautan Universitas Riau. Penempatan stasiun dilakukan dengan purposive sampling yang terdiri dari 3 stasiun dengan 3 transek pada setiap stasiun. Stasiun 1 berada jauh dari pemukiman, Stasiun 2 berada di dekat pemukiman, Stasiun 3 berada di dekat jalur perahu nelayan.

Pengukuran parameter kualitas perairan meliputi: suhu, salinitas, $\mathrm{pH}$ Parameter ini diukur saat air laut pasang dan untuk pengambilan sampel dengan tiga kali pengulangan pada masing-masing stasiun.

Untuk melihat tipe substrat di daerah pengamatan, sampel sedimen dianalisis menggunakan metode ayakan bertingkat (Rifardi, 2008). Sedangkan bahan organik pada sedimen dapat dilakukan dengan metode Loss on Ignition (Mucha et al., 2013).

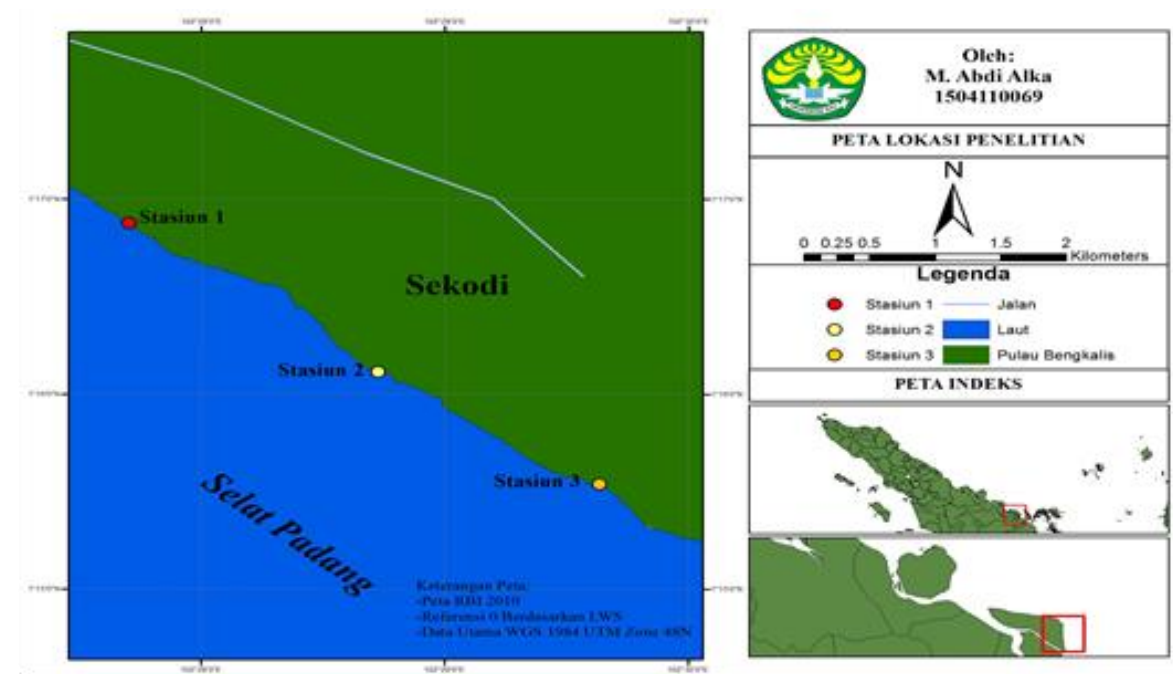

Gambar 1. Peta Lokasi Penelitian

Pengukuran morfometrik menggunakan jangka sorong yang diukur panjang dan lebar. Hubungan lebar-panjang T. telescopium dihitung menggunakan uji
Regresi Linear Sederhana (Tanjung, 2016) dengan rumus :

$$
\mathbf{Y}=\mathbf{a}+\mathbf{b x}
$$


keterangan:

$\mathrm{Y}=$ variabel dependent (terikat)

$\mathrm{a}=$ konstanta $\mathrm{y}$

$\mathrm{b}=$ konstanta $\mathrm{x}$

$\mathrm{x}=$ variabel independent (bebas)

Kepadatan populasi dihitung menggunakan pendekatan menurut Brower et al. (1990) : Untuk mengetahui perbedaan kepadatan antar stasiun menggunakan uji Anova.

$$
\mathrm{Ki}=\frac{\mathrm{Ni}}{\mathrm{A}}
$$

Keterangan :

$\mathrm{Ki}=$ Kepadatan individu jenis ke-i (ind $/ \mathrm{m}^{2}$ )

$\mathrm{Ni}=$ Jumlah individu jenis ke-i (ind)

$\mathrm{A}=$ Luas total area pengambilan sampel $\left(1 \mathrm{x} 1 \mathrm{~m}^{2}\right)$

Analisis nisbah kelamin menggunakan metode (Kandel et al, 2013):

Keterangan :

$$
\mathbf{X}=\frac{\mathbf{B}}{\mathbf{J}} \quad \text { atau } \mathbf{X}=\mathbf{B}: \mathbf{J}
$$

$\mathrm{X}=$ Nisbah kelamin

$\mathrm{J}=$ Jumlah kerang jantan (individu)

$\mathrm{B}=$ Jumlah kerang betina (individu)

Uji keseimbangan nisbah kelamin betina dan jantan dengan menggunakan uji Chi - Square $(\alpha=0,05)$.
3. HASIL DAN PEMBAHASAN Keadaan Umum Daerah Penelitian

Secara geografis, lokasi penelitian terletak di wilayah administrasi Desa Sekodi Kecamatan Bengkalis Kabupaten Bengkalis yang berbatasan dengan Desa Taluk Lancar Kecamatan Bantan di sebelah Utara, Selat Padang dan Kabupaten Kepulauan Meranti di sebelah Selatan, Desa Palkun di sebelah Barat, dan Selat Malaka di sebelah Timur, dengan luas wilayah $39 \mathrm{~km}^{2}$, dengan jarak tempuh 60 $\mathrm{km}$ dari pusat Kota Bengkalis. Desa ini memiliki 4 buah sungai dan 2 buah selat, yakni Selat Malaka dan Selat Padang.

Suhu perairan maksimum $38^{\circ} \mathrm{C}$ dan minimum $22^{\circ} \mathrm{C}$. Aktivitas yang dilakukan masyarakat didaerah tersebut yaitu aktivitas dermaga kecil yang digunakan nelayan untuk transportasi air dan menurunkan hasil tangkapan ikan. Kondisi perairan dari hasil pengamatan di lapangan secara visual adalah seluruh stasiun terlihat keruh dan air bewarna kecoklatan, Serta arus air tergolong tenang.

\section{Parameter Kualitas Air}

Parameter yang diukur pada penelitian ini adalah $\mathrm{pH}$ suhu, dan salinitas. Desa Sekodi memiliki suhu antara 30-32 ${ }^{\circ} \mathrm{C}$, pH 6 dan salinitas antara 28-31 ppt (Tabel 1).

Tabel 1. Parameter Kualitas Air pada Masing-masing Stasiun Pengamatan di Perairan Desa Sekodi.

\begin{tabular}{lccccc}
\hline No. & Parameter Kualitas Air & \multicolumn{3}{c}{ Stasiun } & \multirow{2}{*}{ Rata-rata } \\
\cline { 3 - 5 } & & $\mathbf{1}$ & $\mathbf{2}$ & $\mathbf{3}$ & \\
\hline 1. & Suhu $\left({ }^{\circ} \mathrm{C}\right)$ & 31 & 30 & 32 & 31 \\
2. & $\mathrm{pH}$ & 6 & 6 & 6 & 6 \\
3. & Salinitas $(\mathrm{ppt})$ & 28 & 30 & 31 & 29,6 \\
\hline
\end{tabular}

Berdasarkan Tabel 1 pada rata rata suhu pada perairan desa Sekodi yaitu $31{ }^{\circ} \mathrm{C}, \mathrm{pH}$ pada setiap stasiun memiliki rata - rata 6 dan pada salinitas rata - rata yang didapat pada perairan Desa Sekodi yaitu $29,6 \mathrm{ppt}$

\section{Tipe Sedimen}

Berdasarkan hasil perhitungan analisis fraksi sedimen dan hasil segitiga Sherpard maka didapatkan tipe sedimen pada seluruh stasiun yaitu lumpur berpasir (Tabel 2). 
Tabel 2. Tipe Sedimen Perairan Pantai di Desa Sekodi Kecamatan Bengkalis.

\begin{tabular}{cccc}
\hline \multirow{2}{*}{ Sedimen } & \multicolumn{3}{c}{ Stasiun } \\
\cline { 2 - 4 } & 1 & 2 & 3 \\
\hline Kerikil (\%) & 5,88 & 5,14 & 10,29 \\
Pasir (\%) & 46,26 & 46,11 & 44,53 \\
Lumpur(\%) & 47,85 & 48,75 & 45,19 \\
\hline
\end{tabular}

Tipe sedimen Lumpur Berpasir Lumpur Berpasir Lumpur Berpasir

Berdasarkan Tabel 2 fraksi sedimen setiap stasiun tipe sedimen yang didapat sama yaitu lumpur berpasir dengan persentase lumpur sebesar $47,85 \%$ pada Stasiun 1, 48,75\% pada Stasiun 2 dan 45,19\% pada Stasiun 3.

\section{Bahan Organik Pada Sedimen}

Bahan organik yang didapatkan dari sedimen di Desa Sekodi Kecamatan Bengkalis memiliki perbedaan di setiap stasiun pengamatan. Untuk lebih jelasnya dapat dilihat pada Tabel 3.

Tabel 3. Bahan Organik pada Sedimen Perairan Pantai di Desa Sekodi Kecamatan Bengkalis.

\begin{tabular}{cc}
\hline Stasiun & $\begin{array}{c}\text { Bahan Organik } \\
\text { Pada Sedimen }(\%)\end{array}$ \\
\hline 1 & $5,8307 \%$ \\
2 & $6,062 \%$ \\
3 & $5,2391 \%$ \\
\hline
\end{tabular}

Berdasarkan Tabel 3, bahan organik pada sedimen tertinggi terdapat pada stasiun 2 yaitu $6,062 \%$, Stasiun 1 memiliki rata-rata bahan organik yaitu $5,8307 \%$ dan bahan organik terendah terdapat pada stasiun 3 yaitu 5,2391\%. Tingginya bahan organik pada Stasiun 2 diduga karena limbah rumah tangga yang dibuang oleh penduduk Desa Sekodi dibandingkan pada Stasiun 1 dan 3.

\section{Distribusi Ukuran Cangkang T.telescopium}

Hasil pengukuran morfometrik $T$. telescopium mendapatkan ukuran yang beragam pada setiap stasiun, dimana Stasiun 2 memiliki ukuran yang cenderung lebih kecil dibandingkan stasiun 1 dan 3 (Gambar 2)

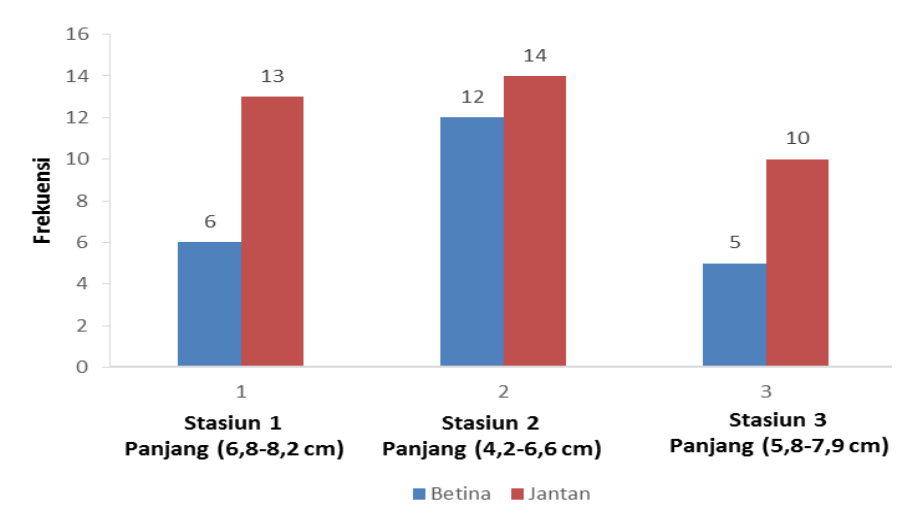

Gambar 2. Ukuran individu T. telescopium (panjang) $\mathrm{cm}$

Gambar 2 diatas panjang $T$. telescopium tertinggi berada pada stasiun 1, setelah itu diikuti pada stasiun 2 dan ukuran panjang terendah terdapat pada stasiun 3. Untuk jumlah individu T.telescopium yang didapat paling banyak 
di stasiun 2 yaitu 26 individu setelah itu diikuti pada stasiun 1 yaitu 19 individu dan jumlah yang paling sedikit terdapat pada stasiun 3 yaitu 15 individu.

Berdasarkan hasil pengamatan dapat dilihat adanya perbedaan morfometri untuk panjang dan diameter Telescopium telescopium yang signifikan pada masingmasing stasiun pengamatan. Rata-rata panjang Telescopium telescopium pada Stasiun 1 yaitu 7,2 $\mathrm{cm}$ dan rata-rata lebar yaitu $3,7 \mathrm{~cm}$. Sementara rata-rata panjang Telescopium telescopium pada Stasiun 2 yaitu $5,7 \mathrm{~cm}$ dan rata-rata lebar yaitu 2,6 $\mathrm{cm}$. Rata-rata panjang Telescopium telescopium pada Stasiun 3 yaitu $5,8 \mathrm{~cm}$ dan rata-rata lebar yaitu $3 \mathrm{~cm}$. Rata-rata panjang dan lebar Telescopium telescopium tertinggi terdapat pada Stasiun 1 yaitu di dalam hutan mangrove yang jauh dari pemukiman dan tidak tercemar.

Sedangkan rata-rata panjang dan lebar Telescopium telescopium terendah terdapat pada Stasiun 2 yaitu di daerah tercemar yang dekat dengan pemukiman dan aktivitas manusia. Pada stasiun 3 ratarata panjang dan lebar Telescopium telescopium berukuran sedang, stasiun 3 berada dekat jalur sungai perahu neleyan. Perbedaan ukuran morfometrik pada setiap stasiun dapat diduga karena disebabkan oleh pengaruh kualitas lingkungan seperti suhu, salinitas, $\mathrm{pH}$ dan makanannya. Menurut Effendie dalam Sunarni (2017) Pertumbuhan suatu biota dapat dipengaruhi oleh dua faktor yaitu faktor internal dan faktor eksternal. Faktor internal yang mempengaruhi pertumbuhan biota yaitu keturunan (genetik), jenis kelamin, parasite dan penyakit, serta umur dan maturitas. Faktor eksternal mempengaruhi pertumbuhan biota yaitu jumlah dan ukuran makanan yang tersedia, jumlah biotayang menggunakan sumber makanan yang tersedia, suhu, oksigen terlarut, kadar amonia di perairan dan salinitas (Moyle dan Cech 2004). Perbedaan morfometrik Telescopium telescopium pada ketiga stasiun pengamatan diduga karena adanya perbedaan aktivitas pada masingmasing stasiun pengamatan. Aktivitas pada setiap stasiun diduga dapat menghambat pertumbuhan dari Telescopium telescopium, sehingga terjadi perbedaan morfometrik antara ketiga stasiun pengamatan. Sreenivasan dan Natarajan (1991) menyatakan bahwa perbedaan ukuran yang ditemukan pada tiap-tiap habitat disebabkan karena ketersediaan pakan dan faktor lingkungan hutan mangrove.

Kondisi keong bakau yang kecil dapat diakibatkan karena lingkungan yang sudah terganggu. Faktor lingkungan yang terganggu dapat mengakibatkan keong bakau stress dan salah satu faktor lingkungan yang dapat menyebabkan hal tersebut adalah kelarutan oksigen yang rendah. Kelarutan oksigen yang rendah dapat diakibatkan oleh bahan organik tinggi yang berasal dari buangan aktivitas tambak atau serasah mangrove (Purnamaningtyas dan Syam 2010).

\section{Hubungan Lebar dan Panjang $T$. telescopium}

Sebaran data panjang dan lebar cangkang berada di sekitar garis regresi Y $=3,3613+1,0328 \mathrm{X}$, dengan nilai $\mathrm{r}=$ 0,4960. Hal ini berarti setiap kenaikan $1 \mathrm{~cm}$ lebar cangkang akan diikuti kenaikan $1,0328 \mathrm{~cm}$ panjang cangkang. Selanjutnya hubungan panjang dan lebar cangkang dihubungkan dengan garis regresi linear yang dapat dilihat pada Gambar 4, 5 dan 6 . 


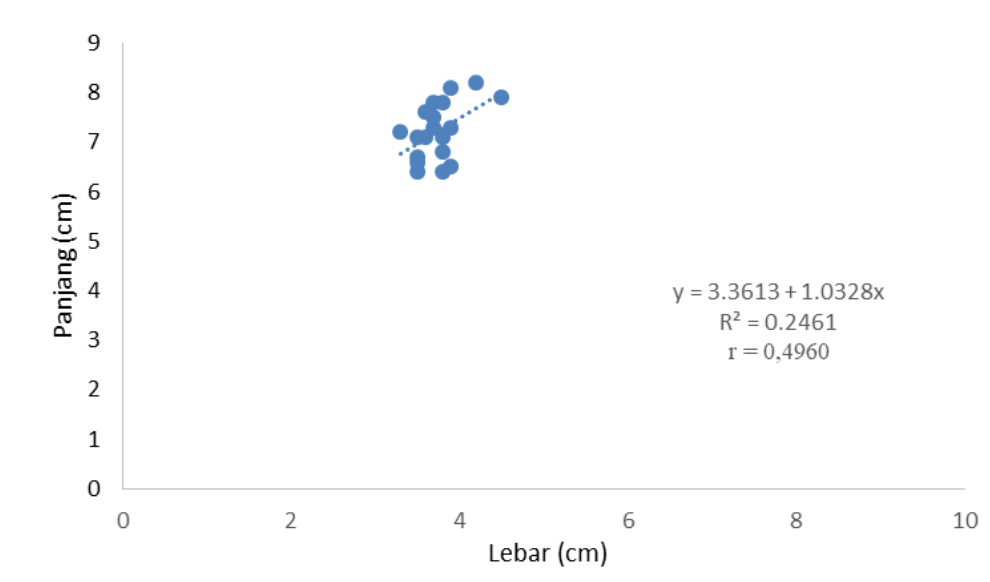

Gambar 3. Hubungan Panjang dan Lebar Cangkang Stasiun 1

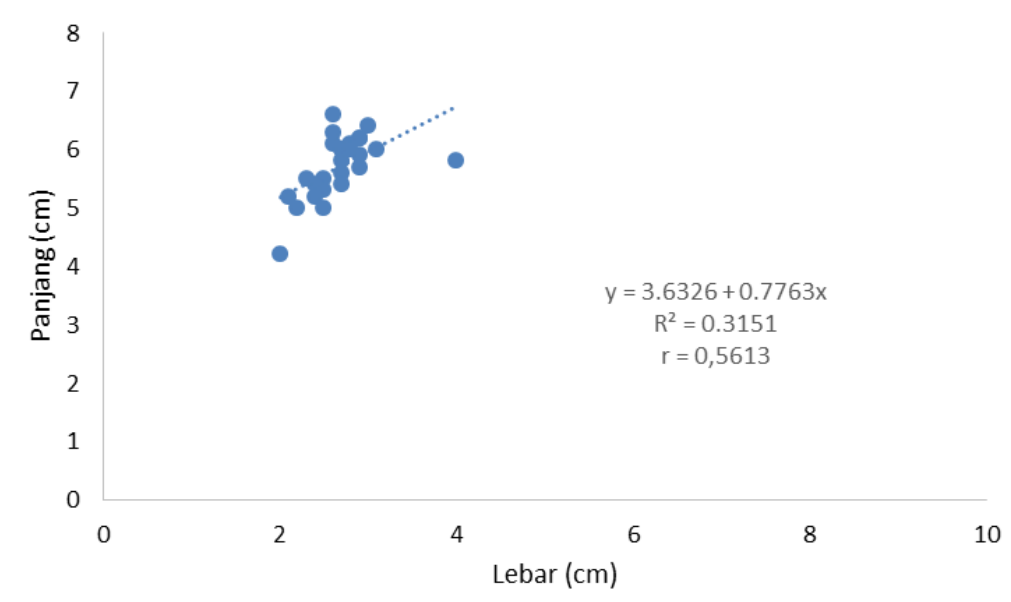

Gambar 4. Hubungan Panjang dan Lebar Cangkang Stasiun 2

Gambar 4 menunjukkan bahwa sebaran data panjang dan lebar cangkang berada di sekitar garis regresi $\mathrm{Y}=3,6326+$ $0,7763 X$, dengan nilai $r=0,5613$. Hal ini berarti setiap kenaikan $1 \mathrm{~cm}$ lebar cangkang akan diikuti kenaikan $0,7763 \mathrm{~cm}$ panjang cangkang.

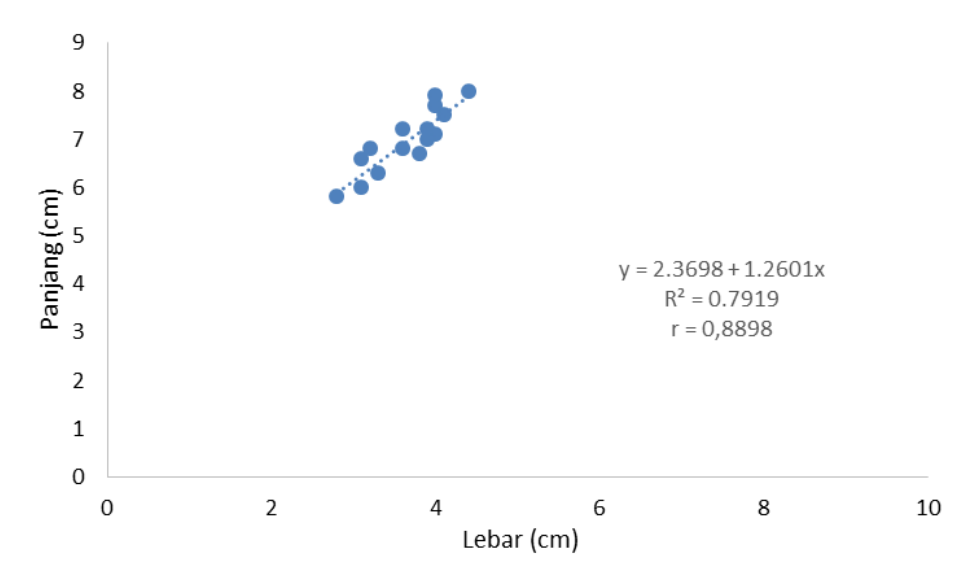

Gambar 5. Hubungan Panjang dan Lebar Cangkang Stasiun 3 
Gambar 5 menunjukkan bahwa sebaran data panjang dan lebar cangkang berada di sekitar garis regresi $\mathrm{Y}=2,3698+$ $1,2601 X$, dengan nilai $r=0,8898$. Hal ini berarti setiap kenaikan $1 \mathrm{~cm}$ lebar cangkang akan diikuti kenaikan 1,2601 cm panjang cangkang.

\section{Kepadatan T.telescopium}

Kepadatan T. telescopium di Desa Sekodi Kecamatan Bengkalis mendapatkan nilai kepadatan yang beragam antar stasiun (Gambar 7).

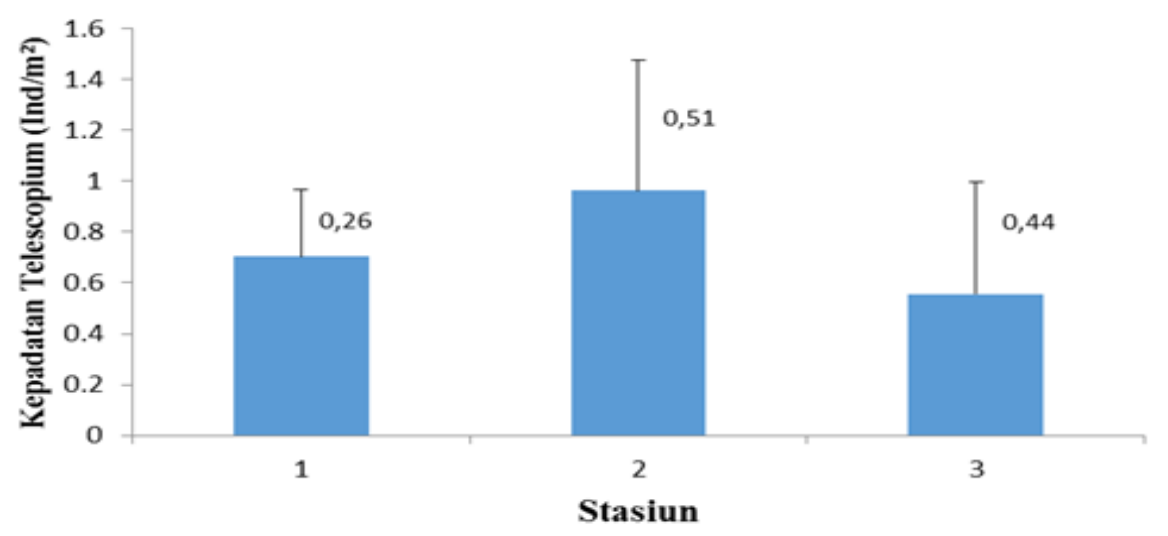

Gambar 6. Kepadatan (Rata-rata Standar Deviasi) T. telescopium Pada Masing-masing Stasiun Pengamatan di Desa Sekodi Kecamatan Bengkalis

Berdasarkan Gambar 6, kepadatan tertinggi terdapat pada Stasiun $2 \quad(0,96$ $\mathrm{ind} / \mathrm{m}^{2}$ ) berada dekat pemukiman, kepadatan terendah terdapat pada stasiun 3 $\left(0,55 \mathrm{ind} / \mathrm{m}^{2)}\right.$ berada pada daerah jalur perahu nelayan dan pada stasiun $1(0,7$ ind $/ \mathrm{m}^{2}$ ) jauh dari pemukiman kepadatan nya sedang. Selanjutnya, hasil analisis yang diperoleh dari Uji ANOVA menunjukkan angka $\mathrm{F}$ tabel $>\mathrm{F}$ hitung $(3,40>2,18)$ yang berarti tidak ada perbedaan kepadatan yang nyata antar stasiun.

Kepadatan T. telescopium memperlihatkan tidak adanya perbedaan yang nyata antara stasiun yang satu dengan lainnya. Kepadatan tertinggi terdapat pada Stasiun $2\left(0,96 \mathrm{ind} / \mathrm{m}^{2}\right)$, disusul dengan Stasiun $1\left(0,7 \mathrm{ind} / \mathrm{m}^{2}\right)$, dan terendah pada stasiun Stasiun $3 \quad\left(0,55 \quad \mathrm{ind} / \mathrm{m}^{2}\right)$. Berdasarkan nilai standar deviasi kepadatan rara-rata $T$. telescopium menggambarkan bahwa variasi nilai kepadatan pada Stasiun 2 sangat tinggi, dan terendah pada Stasiun 1. Tingginya variasi kepadatan
T.telescopium pada Stasiun 2 diduga adanya pengaruh dari aktivitas masyarakat sekitar.

Tingginya nilai kepadatan $T$. telescopium dikarenakan jenis gastropoda ini hidup dan berkembang di kawasan mangrove dalam jumlah besar terutama di sebagian besar jenis substrat berlumpur (Masagca et al., 2010). Hasil ini sesuai dengan penjelasan Dharma (1988) dan Budiman (1988) yang melaporkan bahwa hutan mangrove merupakan habitat yang paling disukai untuk famili Potamididae serta memiliki distribusi geografis yang luas dan juga ditemukan dalam kelimpahan yang tinggi di ekosistem mangrove. Odum (1996) juga menjelaskan bahwa suatu spesies dengan kepadatan tertinggi menunjukkan bahwa organisme tersebut memiliki kemampuan menempati ruang yang lebih luas sehingga memiliki kemampuan berkembang lebih banyak.

Tingginya kepadatan $T$. telescopium di Stasiun 2 sesuai dengan kandungan 
bahan organik. Sesuai dengan pendapat Tis'in (2008) yang mengatakan bahwa populasi gastropoda terkait erat dengan kerapatan mangrove. Diduga bahwa kepadatan populasi $T$. telescopium yang tinggi dipengaruhi oleh bahan organik dan kerapatan mangrove. Selain itu Stasiun 1 dan 2 mempunyai nutrien yang lebih tinggi dari pada Stasiun 3, sehingga dapat dikatakan bahwa tingginya kepadatan $T$. telescopium juga diiringi oleh tingginya kandungan nutrien pada ekosistem mangrove.

Penelitian yang dilakukan oleh Haryoardyantoro et al. (2013) menunjukkan bahwa nilai kepadatan gastropoda tinggi pada jenis mangrove dan bahan organik yang sama dan memiliki kerapatan yang lebat. Hasil yang sama juga ditunjukkan oleh penelitian Mentarijuita et al. (2014) hutan mangrove Pantai Maron memiliki kepadatan ekosistem mangrove yang sangat padat, mendapatkan nilai tertinggi.

Pengaruh parameter lingkungan seperti salinitas, pasang surut dan substrat memiliki korelasi positif dengan distribusi dan kepadatan gastropoda. Distribusi spesies ini mengikuti pola pergerakan pasang dan surut air laut. Menurut Derbali et al. (2012), keberadaan spesies gastropoda juga dipengaruhi oleh pergerakannya pada saat pasang naik yang merupakan penghindaran dari pemangsaan.

Ukuran individu T. telescopium diperoleh tiga kelas ukuran, yaitu kecil, sedang, dan besar. Semua kategori kelas ukuran dapat ditemukan pada ketiga stasiun, namun distribusi frekuensi kelas ukuran memperlihatkan perbedaan antar stasiun. T. telescopium yang berukuran sedang merupakan ukuran yang paling banyak ditemukan pada semua lokasi penelitian. Ukuran besar terbanyak ditemukan pada Stasiun 1, hal ini menandakan bahwa Stasiun 1 merupakan penyedia habitat paling baik untuk mendukung kehidupan T. telescopium, baik sebagai sumber makanan maupun habitat. Menurut Uneputty dan Daniel (2011) bahwa besarnya suatu organisme perairan dipengaruhi oleh faktor makanan. Makanan merupakan sumber energi potensial yang dapat digunakan untuk melakukan segala keaktifan baik untuk pemijahan maupun pertumbuhan

Keterlindungan lokasi Stasiun 1 pula yang mengakibatkan $T$. telescopium tidak tereksploitasi secara maksimal oleh nelayan, dikarenakan lokasinya yang jauh dari pemukiman warga. Menurut pendapat beberapa nelayan dan pengepul di Desa Sekodi, sebagian besar nelayan lebih memilih lokasi yang lebih dekat dan terbuka aksesnya untuk menangkap $T$. telescopium. Hal ini yang diduga sebagai alasan distribusi kelas ukuran sedang hingga besar lebih banyak di Stasiun 1 .

\section{Nisbah Kelamin}

Pada Stasiun 1 nisbah kelamin perbandingan 1:2,16. Sasiun 2 memiliki perbandingan 1:1,16. Selanjutnya Stasiun 3 memiliki perbandingan 1:2. Berdasarkan hasil uji chi-square menunjukkan bahwa semua stasiun memiliki nilai $\chi^{2}$ Hitung $<\chi^{2}$ Tabel yang artinya ada tidak perbedaan antara jumlah betina dan jantan yang berarti nisbah kelamin $T$. telescopium di Desa Sekodi berada dalam keadaan seimbang.

Nisbah kelamin $T$. telescopium di Desa Sekodi Kecamatan Bengkalis menunjukkan adanya perbedaan jumlah populasi jantan dan betina. Lebih jelasnya dapat dilihat pada Tabel 4 dan Gambar 7. 
Tabel 4. Nisbah kelamin T. telescopium pada Masing-masing Stasiun Pengamatan di Desa Sekodi Kecamatan Bengkalis

\begin{tabular}{cccccccc}
\hline Stasiun & Transek & $\begin{array}{c}\text { Jumlah } \\
\text { Betina }\end{array}$ & $\begin{array}{c}\text { Jumlah } \\
\text { Jantan }\end{array}$ & $\begin{array}{c}\text { Betina : } \\
\text { Jantan }\end{array}$ & $\begin{array}{c}\chi^{2} \\
\text { Hitung }\end{array}$ & $\begin{array}{c}\chi^{2} \\
\text { tabel }\end{array}$ & Kategori \\
\hline \multirow{2}{*}{1} & 1 & 2 & 4 & & & & \\
& 2 & 2 & 4 & $1: 2,16$ & 2,579 & 3,841 & Seimbang \\
& 3 & 2 & 5 & & & & \\
\hline \multirow{2}{*}{2} & 1 & 2 & 4 & & & & \\
& 2 & 7 & 4 & $1: 1,16$ & 0,154 & 3,841 & Seimbang \\
& 3 & 3 & 6 & & & & \\
\hline \multirow{3}{*}{3} & 1 & 2 & 5 & & & & \\
& 2 & 2 & 3 & $1: 2$ & 1,667 & 3,841 & Seimbang \\
\hline
\end{tabular}

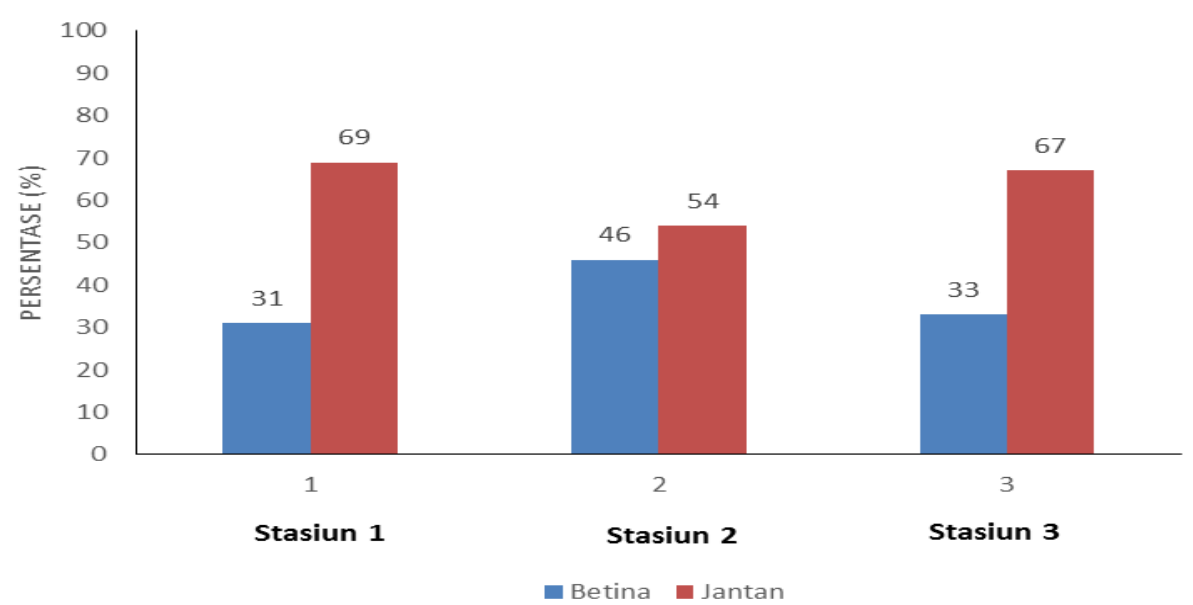

Gambar 7. Nisbah Kelamin T. telescopium pada Masing-masing Stasiun Pengamatan di Desa Sekodi Kecamatan Bengkalis

Gambar 7, bahwa pada setiap stasiun yang di amati jumlah siput $T$. telescopium dengan jenis kelamin jantan lebih banyak dibandingkan jenis kelamin betina. Stasiun 1 memiliki $69 \%$ jantan dan $31 \%$ betina, stasiun 2 memiliki 54\% jantan dan $46 \%$ betina dan stasiun 3 memiliki $67 \%$ jantan dan $33 \%$ betina.

Nisbah kelamin siput bakau di ekosistem mangrove Desa Sekodi Kecamatan Bengkalis sangat mendukung keberlangsungan fertilisasi telur oleh sel sperma, yaitu 2:1. Kecukupan sel sperma dalam membuahi telur sangat penting. Ditambah lagi pembuahan telur oleh sperma pada kebanyakan siput termasuk siput bakau berlangsung secara internal, sehingga menjadi sangat penting keberadaan pasangannya.
Analisis chi square menemukan tidak adanya perbedaan pada nisbah kelamin jantan terhadap betina ( $\chi^{2}$ Hitung < $\chi^{2}$ Tabel). Rasio keong jantan lebih besar dibandingkan rasio keong betina. Rasio kelamin jantan dan betina pada saat pengamatan adalah 2:1. Hal ini dikatakan seimbang dikarenakan optimalnya sel sperma membuahi sel telur. Hasil rasio kelamin diduga dipengaruhi oleh perbedaan kecepatan pertumbuhan antara keong jantan dan betina yaitu pertumbuhan rata-rata keong jantan lebih cepat dibandingkan pertumbuhan rata-rata betina (Martanti, 2001). Rasio kelamin jantan dan betina yang seimbang hal ini terjadi karena pada daerah penelitian, tekanan eksploitasi cenderung rendah. Dukungan lingkungan yang baik untuk pertumbuhan sehingga 
diduga rasio kelamin jantan dan betina cenderung sama. Sebagaimana dikatakan, bahwa perubahan faktor lingkungan dapat mengakibatkan perubahan rasio kelamin jantan dan betina (Natan, 2008; Rochmady, 2011). Nisbah kelamin sebagai salah satu parameter reproduksi diukur untuk menentukan kemungkinan tersedianya induk jantan dan induk betina yang diharapkan dapat terjadi pemijahan. Dalam kondisi normal, rasio jenis kelamin jantan dan betina ditunjukkan dengan rasio jenis kalamin jantan dan betina antara satu (1) jantan berbanding satu (1) betina. Selain itu, nisbah kelamin dapat pula menunjukkan adanya eksploitasi yang berlebihan terhadap salah satu jenis kelamin maupun indikasi adanya perubahan lingkungan (Effendie, 1997).

Nisbah kelamin yang seimbang antara jantan betina diperoleh pada $T$. telescopium di Pelabuhan Darwin Australia French (2013). Namun ini tidak sesuai dengan yang dikemukakan oleh Webber dalam French (2013), bahwa kebanyakan spesies siput laut lebih banyak betina dari pada yang jantan. Effendi (2002) menyatakan bahwa di alam perbandingan antara jantan betina terjadi penyimpangan dari pola 1:1 yang di sebabkan oleh pola tingkah laku bergerombol antara jantan dan betina. Hal ini di pengaruhi oleh pola hidup yang disebabkan oleh ketersediaan makanan, kepadatan populasi, dan keseimbangan rantai makanan, penyimpangan dari kondisi ideal disebabkan oleh faktor tingkah laku, perbedaan laju mortalitas, dan pertumbuhannya. Keseimbangannya rasio kelamin dapat berubah menjelang pemijahan.

\section{KESIMPULAN DAN SARAN Kesimpulan}

Rata-rata panjang dan lebar Telescopium telescopium tertinggi terdapat pada Stasiun 1 yaitu di dalam hutan mangrove yang jauh dari pemukiman. Sedangkan rata-rata panjang dan lebar terendah terdapat pada Stasiun 2 yaitu di daerah yang dekat dengan pemukiman dan aktivitas manusia.

Kepadatan T. telescopium memperlihatkan adanya perbedaan antara stasiun yang satu dengan lainnya. Kepadatan tertinggi terdapat pada Stasiun yang berada pada daerah dekat dengan pemukiman, disusul dengan Stasiun yang berada pada daerah yang jauh dari pemukiman, dan terendah pada stasiun yang berada didaerah jalur perahu nelayan. Jumlah antara kelamin jantan dan betina yang didapat seimbang $\left(\chi^{2}\right.$ Hitung $<\chi^{2}$ Tabel).

\section{Saran}

Perlu dilakukan penelitian lanjutan tentang pembeda antara jenis kelamin jantan dan betina dilihat dari bentuk atau morfologi cangkangnya.

\section{DAFTAR PUSTAKA}

1. Amin, B., A. Ismail, A. Arshad and CK. Yap and MS. Kamarudin. (2009). Gastropod assemblages as indicators of sediment metal contramination in mangrove of Dumai, Sumatra, Indonesia. Water, Air and Soil pollution, volume 201, pages 9-18.

2. Badan Pusat Statistik Kabupaten Bengkalis. 2015. Kabupaten Bengkalis Dalam Angka 2015. Bengkalis (245): BPS Kab. Bengkalis.

3. Brower, J., Z. Jernold, C. Von Ende. (1990). Filed and Laboratory Methode for General Ecology. Third Edition. USA: W. M. C. Brown Publisers.

4. Budiman, A. (1988). Some aspects on the ecology of Mangrove Whelk Telecospium Telecospium (Linne, 1758) (Mollusca, Gastropoda: Potamididae). Treubia, volume 29(4), pages 237-245. 
5. Derbali, A., K. Elhasni, O. Jarboui. (2012). Distribution, Abundance and Biological Parameters of Cerastoderma glaucum (Mollusca:Bivalvia) along the Gabes Coasts (Tunisia, Central Mediterranean). Cienc. Mar. Acta Adriatica. Volume 53, pages 363374.

6. Dharma, B. (1988). Siput dan Kerang Indonesia (Indonesian Shells I). Penerbit : PT. Sarana Graha. Jakarta.

7. Effendi, MI. (2002). Biologi Perikanan. Yogyakarta: Yayasan Pustaka Nusatama.

8. French, VA. (2013). An Investigation of Microcontaminant Impacts in Darwin Harbour Using the Tropical Marine Snail Telescopium telescopium. Thesis for Doctor of Philosophy. Faculty of Engineering, Health, Science and Environmental Charles Darwin University.

9. Haryoardyantoro, S., R. Hartati, dan Widianingsih. (2013). Komposisi dan Kelimpahan Gastropoda di Vegetasi Mangrove Kelurahan Tugurejo, Kecamatan Tugu, Kota Semarang. Journal of Marine Research, volume 2(2), pages 85-93.

10. Kandel, KE., S. Mohammad, AM. Mostafa dan AMA. Alla. (2013). Reproductive biology of the cockle Cerastoderma glanser (Bivalvia: Cardiidae) foom lake Qarun, Egypt. The Egyptian Journal of Aquatic Research, volume 3(4), pages 249-260.

11. Martanti, D. (2001). Pola Distribusi dan Struktur Populasi Keong Macan (Babylonia spirata L.) di Teluk Pelabuhan Ratu pada Musim Timur. Skripsi (tidak dipublikasikan). Bogor : Program Studi Manajemen Sumberdaya Perikanan. Fakultas Perikanan dan Ilmu Kelautan. Institut Pertanian Bogor.

12. Masagca, JT., AV. Mendoza and ET. Tribiana. (2010). The Status of Mollusk Diversity and Physical Setting of the Mangrove Zones in Catanduanes Island, Luzon, Philippines. BIOTROPIA, volume 17(2), pages $62-76$

13. Mentarijuita, R., N. Soenardjo, dan I. Ritniatsih. (2014). Keberadaan Komunitas Makrozoobenthos pada Kondisi Ekosistem Mangrove yang Berbeda di Pesisir Semarang. Journal of Marine Research, volume 3(3), pages 14-23.

14. Moyle PB and JJ. Cech (2004). Fishes. An Introduction to Ichthyology. 5thed. USA: Prentice Hall, Inc.

15. Mucha, AP., MTSD. Vasconcelos and AA. Bordalo. (2003). Macrobenthic Community in the Douro Estuary Relation With Trace Metals and Natural Sediment Characteristic. Journal Environment Pollution, volume 121, pages 160-180.

16. Natan, Y. (2008). Studi Ekologi dan Reproduksi Populasi Kerang Lumpur Anodontia edentula Pada Ekosistem Mangrove Teluk Ambon Bagian Dalam. Disertasi. Program Studi Ilmu dan Teknologi Kelautan. Institut Pertanian Bogor. Bogor. 179 hlm

17. Odum, EP. (1996). Dasar - Dasar Ekologi. Alih Bahasa. Cahyono,S. FMIPA IPB. Gadjah Mada University Press. 625p.

18. Purnamaningtyas SE, dan AR. Syam. (2010). Kajian Kualitas Air dalam Mendukung Pemacuan Stok Kepiting Bakau di Mayangan Subang, Jawa Barat. LIMNOTEK volume $17(1)$, pages 85-93.

19. Rochmady. (2011). Aspek Bioekologi Kerang Lumpur Anodontia edentula Linnaeus, 1758 di Perairan Pesisir Kabupaten Muna. Tesis. Program Studi Ilmu Perikanan, Program Pascasarjana, Universitas Hasanuddin. Makassar.

20. Rusyana, A. (2011). Zoologi Invertebrata. Bandung: Alfabeta.

21. Sreenivasan, PV. dan R. Natarajan. 1991. Potamidid Snails of Vellar-Coleroon Estuarine Area, Southeast Coast of India. J. Mar. Biol. Ass. India, volume 33(1\& 2), pages 385395. 
22. Sunarni. (2017). Hubungan Panjang Bobot dan Faktor Kondisi Ikan Belanak (Mugil dussumieri) di Muara Sungai Kumbe Kabupaten Merauke. J. Agricola, volume 7(1), pages 136-143.

23. Tanjung, A. 2016. Rancangan Percobaan Edisi Revisi. Tantama mesra. Bandung.

24. Tis'in, M. 2008. Tipologi Mangrove dan Keterkaitannya dengan Populasi Gastropoda Littorina neritoides (LINNE, 1758) di Kepulauan Tanakeke Kabupaten Takalar, Sulawesi Selatan. Tesis. Bogor: Institut Pertanian Bogor, Bogor.

25. Unneputty, PA dan D. Tanjung. 2011. Karakteristik Biometrika dan Potensi Reproduksi Siput Abalone (Haliotis squamata). Ichthyos, volume 10(1), pages 13-20. 